\title{
E-justice in civil cases and economic disputes in the Russian Federation
}

\section{Justicia electrónica en asuntos civiles y disputas económicas en la Federación de Rusia}

\author{
DOI: https://doi.org/10.17981/juridcuc.17.1.2021.22
}

Fecha de Recepción: 2021/01/28 Fecha de Aceptación: 2021/04/21

\author{
Inna Leonidovna Burova \\ Russian State Social University. Moscow (Russian Federation) \\ burova.i.1@mail.ru \\ Maria Alexandrovna Volkova \\ Russian State Social University. Moscow (Russian Federation) \\ maria.a.volkova@bk.ru \\ Renata Romanovna Lenkovskaya \\ Russian State Social University. Moscow (Russian Federation) \\ lenkovskaya.r.r@inbox.ru
}

Para citar este artículo:

Burova, I., Volkova, M. \& Lenkovskaya, R. (2021). E-justice in civil cases and economic disputes in the Russian Federation. Jurídicas CUC, 17(1), 629-648. DOI: http://dx.doi.org/10.17981/juridcuc.17.1.2021.22

\section{Resumen}

Se analizaron los últimos cambios en la legislación de la Federación de Rusia, dirigidos al desarrollo de la justicia electrónica en asuntos civiles y arbitrales. Los principales métodos de este estudio fueron formal-legal, comparativo-legal y sistemático. Se valoraron positivamente la introducción de tecnologías digitales en el ámbito de la protección judicial de los derechos y los intereses protegidos por la ley, de los ciudadanos y organizaciones en la Federación de Rusia. Se observa que la informatización de los procedimientos judiciales y legales servirá como un medio eficaz para implementar los principios de transparencia y acceso de la justicia en la Federación de Rusia. El uso de elementos de la justicia electrónica, como la presentación electrónica de documentos, la participación en una reunión mediante videoconferencia, el registro de audio y video, la posibilidad de que las personas involucradas en el caso obtengan protocolos de audio y video a través de sistemas electrónicos de comunicación, la notificación a los participantes en el proceso utilizando recursos como la "guardia electrónica", la notificación por SMS, etc., tiene como objetivo mejorar la calidad de la justicia rusa. A pesar de la evaluación general positiva de los cambios en la legislación de la Federación de Rusia sobre justicia electrónica, los autores señalan sus deficiencias individuales. El artículo refleja los problemas de la regulación normativa de la justicia electrónica en la Federación de Rusia y propone formas de resolver conflictos legales.

Palabras clave: Acceso a la justicia; arbitraje; justicia electrónica; procedimientos legales electrónicos; proceso civil; transparencia de la justicia

\section{Abstract}

The authors of the article have analyzed the latest amendments made to the legislation of the Russian Federation aimed at the development of e-justice in civil and arbitration cases. The main methods of this study were formal-legal, comparative-legal and systematic. The authors positively assess the introduction of digital technologies into the field of judicial protection of the rights and interests of citizens and organizations in the Russian Federation. It seems that the informatization of legal proceedings and records management will serve as an effective means of implementing the principles of transparency and accessibility of justice in the Russian Federation. The use of e-justice aims at improving the quality of justice in the Russian Federation. Its components are as follows: filing documents in electronic form, meetings held through video conferencing, audio and video recording, receiving audio and video protocols through electronic communication systems by parties to some case, notifying parties using such resources as "Guard Arbiter", SMS, etc. Despite the general positive assessment of the amendments made to the Russian legislation on e-justice, the authors emphasize its certain shortcomings. The article dwells on the statutory regulation of e-justice in the Russian Federation and suggests possible ways to resolve legal conflicts.

Keywords: Access to justice; arbitration proceedings; civil proceedings; e-justice; e-judicial proceedings; transparency of justice 


\section{INTRODUCTION}

During the development of digital technologies, e-justice plays a crucial role in ensuring the accessibility and transparency of judicial protection of civil rights in all countries of the world, including the Russian Federation (R.F.). In addition, the recent events related to the spread of coronavirus infection $(2019-\mathrm{nCoV})$ have shown that the administration of justice through digital technologies can be the only form of judicial protection of the rights of citizens and organizations in circumstances of force majeure.

On March 18, 2020, the Presidium of the Supreme Court of the Russian Federation and the Presidium of the Judicial Council of the Russian Federation issued Decree No. 808 (2020). According to this document, the personal reception of citizens in all courts in the territory of the Russian Federation was suspended from March 19, 2020 through April 10, 2020, and all applicants were recommended to submit their documents through the Internet or by mail. Furthermore, all courts were given an order to hold trials through video conferencing systems if they have technical capabilities. The decree allowed the direct participation of judges in court hearings on some urgent cases (on protecting the interests of a minor child or a person who was declared legally incompetent if their legal representative refuses medical treatment necessary to save the life, etc.) (Shilovskaya \& Sitdikova, 2018). These restrictions did not apply to the cases considered in the form of summary or simplified procedures without the parties appearing at the hearing, which is based on the exchange of written documents between the parties and the court, including the use of such electronic resources as "My arbiter" and "Justice state information system". From April 2020, in Russian arbitration courts, the parties can participate in processes using the information portal of arbitration courts (https://kad.arbitr.ru).

The legal basis for developing e-justice in the Russian Federation was laid by Federal Law No. 149 FZ (2006) "on Information, Information Technologies and Information Security" (as amended and supplemented, entered into force on December 13, 2019) and Federal 
Law No. 262 (2008) "on Providing Access to Data on the Operation of Courts in the Russian Federation" (as amended on December $28,2017)$. Starting from the adoption of the above-mentioned laws, e-justice has become an important component of civil and arbitration proceedings in the Russian Federation ${ }^{1}$. Over ten consecutive years, the information portals of arbitration courts have received numerous automation devices for the creation, deletion, modification, internal and external exchange of electronic documents.

Although courts of general jurisdiction aim at protecting the rights of citizens who may not have sufficient skills in using digital technologies, these institutions have gradually introduced certain elements of e-justice. Initially, innovations in the field of civil proceedings came down to the use of SMS to inform the parties to the trial about the upcoming court session, the application of video conferencing tools during the court session if the court has such technical capabilities, the issuance of judicial acts and writs of execution in the form of electronic documents validated by the judge's electronic digital signature. Meanwhile, the civil procedural legislation of the Russian Federation grants parties more opportunities to carry out legally significant actions remotely using digital technologies.

In particular, significant changes were caused by the adoption of federal laws on amendments to the Civil Procedure Code of the Russian Federation (Federal Law No. 451-FZ, 2018 and Federal Law No. 197-FZ, 2019), obliging courts of general jurisdiction considering civil cases to post information on the acceptance of a claim, the time and place of the court hearing or the commission of a separate procedure on their official website within 15 days; to fill their judicial decision on the adoption of a claim with the official website, its email address to let the parties send and receive information about the case under consideration and other data provided for by

1 The Russian arbitration courts are state courts operating under Federal Constitutional Law No. 1-FKZ (1995, as amended on July 18, 2019) that administer justice by resolving economic disputes among legal entities, self-employed entrepreneurs and public authorities, as well as consider other cases transferred to their competence by federal laws based on the rules of court proceedings established by the Arbitration Procedure Code of the Russian Federation. 
the Civil Procedure Code of the Russian Federation. There are more innovations of the civil legislation of the Russian Federation in the field of e-justice that were positively evaluated by scholars and practicing lawyers (Denisov, 2018; Rybkina, 2018; Usova, 2018; Borisova, 2019; Bryantseva \& Soldatkina, 2019; Vorontsova, 2019; Yakovleva, 2019). At the same time, the legislator has not fixed all the gaps and contradictions in the regulation of such public relations. This article proposes ways to resolve the existing problems concerned with the legal regulation of e-justice in the Russian Federation.

The main methods of this study were formal-legal, comparativelegal and systematic. The formal-legal method was used to analyze the legal foundations of e-justice in the Russian civil process, to study its development and improvement prospects. It was utilized the comparative-legal method to consider the foreign application of e-justice, compare it with the Russian experience and determine possible areas for experience exchange. The historical method let us examine the historical foundations of e-justice in the Russian civil process, analyze the time context of judicial reforms and determine the further development of the legislation that introduced e-justice into the Russian legal system.

\section{Discussion}

Changes introduced in the Russian legislation for the development of e-justice in the field of civil cases and economic disputes are positively assessed. The current measures should raise confidence in the Russian justice and make the Russian economy more attractive for both national and foreign investors. However, it is not possible to appraise all the activities undertaken by the state to digitalize justice. In particular, it is impossible to highly evaluate the creation of an electronic archive of court cases. Given the time-consuming and costly nature of this procedure, it can believe that a qualitative breakthrough will be made by introducing new rules obliging the persons involved in some case to present procedural documents and written evidence with digital copies in the form of scanned docu- 
ments attached into the Arbitration Procedure Code of the Russian Federation (No. 95-FZ, 2002, as amended on December 2, 2019). It seems that the business entities involved in arbitration proceedings have technical and material capabilities to implement this measure. At the same time, it is unacceptable to assign this obligation to regular citizens in the framework of civil proceedings since it can be interpreted as an additional obstacle to justice.

It is also worth highlight the following promising areas of justice informatizzation: the creation of specialized cloud software for automating judicial and general records management, which enables the remote participation of parties to procedural actions from anywhere in the world having a device with Internet access. The state is responsible for developing and implementing technical and legal mechanisms for identifying the party's personality and verifying their authority. It is also responsible for ensuring the confidentiality of information voiced during the consideration of cases in closed court sessions.

It is noted the need to amend the current Russian procedural codes to legitimize online meetings held during the pandemic.

In addition, it seems to be a good idea to form mobile courts using video conferencing tools to conduct on-site meetings in remote settlements.

In the Russian Federation, qualitative changes in the field of e-justice have been caused by the adoption of the following regulations:

- Federal Law No. 149-FZ (2006) "on Information, Information Technologies and Information Security" (as amended and supplemented, entered into force on December 13, 2019).

- Federal Law No. 262-FZ (2008) "on Providing Access to Data on the Operation of Courts in the Russian Federation" (as amended on December 28, 2017).

- Federal Law No. 228-FZ (2010) "on Amending the Arbitration Procedure Code of the Russian Federation" (as amended on June $28,2014)$. 
- Federal Law No. 200-FZ (2011) "on Amending Certain Legislative Acts of the Russian Federation Due to the Adoption of the Federal Law on Information, Information Technologies and Information Security" (as amended on December 29, 2017).

- Federal Law No. 86-FZ (2012) "on Amending the Arbitration Procedure Code of the Russian Federation to Simplify Court Proceedings" (as amended on March 2, 2016).

- Federal Law No. 166-FZ (2013) "on Amending Some Legal Acts of the Russian Federation".

The adoption of the above-mentioned laws stirred up an active discussion among legal scientists considering access to justice through information technologies in the Russian Federation (Vasnev, 2008; Vdovina, 2009; Fedoseeva, 2008; Fedoseeva, 2011; Fokov, 2011; Reshetnyak, 2011; Spitsin, 2011; Dorzhiev, 2012; Rogozhin, 2012; Yachmenev, 2012; Sitdikova \& Starodumova, 2019). The development of e-justice began with the placement of information and reference kiosks in all arbitration courts of the Russian Federation. Using their automated information system, visitors got access to information on the activities of arbitration courts. At the same time, court's calendars and adopted judicial acts are downloaded from the automated information system "Bank of Arbitration Court Decisions".

However, the most efficient and demanded method of informing about e-justice was the publication of data on the activities of arbitration courts on the Internet. One of the first decrees on online access to information about the system of arbitration courts of the Russian Federation was issued in 2007, when the Supreme Arbitration Court of the Russian Federation issued Letter No. VAS-S01/ UIS-984 (2007). This document comprises mandatory requirements for the content published on the official websites of arbitration courts. As compared with 2007, the websites of judicial bodies have undergone serious changes. Now they fully comply with the Federal Law No. 262-FZ (2008, art. 14). In particular, the official websites of arbitration courts provide information on their contacts 
and structures, procedures for submitting documents and paying the state fee, public procurement, conciliation procedures (including mediation), court's calendars, etc. However, the section we should pay special attention to is called "e-justice" and is concerned with online services.

Due to e-justice, every citizen can receive up-to-date information on the procedural actions committed by parties to a trial and arbitration courts in the form of a notification from "Guard Arbiter". In addition, each person can get access to the "Bank of Arbitration Court Decisions". According to the Federal Law No. 262-FZ (2008, art. 15), all the judicial acts adopted by arbitration courts of the Russian Federation, except for judicial acts relating to national security and other confidential information protected by law, are posted on the Internet in full. The process of posting documents is fully automated and all judicial acts are published on the portal within five days from their adoption date.

The automated information system "Bank of Arbitration Court Decisions" was established in mid-2008, which allowed the arbitration system of the Russian Federation to take its rightful place among authoritative judicial publication systems, including Public Access to Court Electronic Records (PACER), Canadian Legal Information Institute (CanLII), British and Irish Legal Information Institute (BAILII), Elektronisches Gerichtsund Verwaltungs postfach (EGVP), etc. Furthermore, the information system "Bank of Arbitration Court Decisions" has advantages over many foreign systems, i.e. it is a free unified resource with data on all court cases and documents (including adopted judicial acts).

Through e-justice, parties to a trial can receive information on the relevant court's calendars.

The "electronic file cabinet" is filled with information on all the cases ever considered by arbitration courts of the Russian Federation. It provides data on both completed court cases and cases pending before the court. Users of mobile devices running on Android and users of iPad tablets can also have access to the file cabinet of arbitration courts. 
Due to the adoption and enactment of Federal Law No. 228-FZ (2010), several innovations have been introduced into arbitration proceedings. Enabling the use of video conferencing systems, submission of electronic documents, filling the samples posted on the official website of arbitration courts, use of audio recording tools to record the course of a court hearing in arbitration courts or courts of appeal, as well as the notification of parties to a trial about the time and location of arbitration proceedings on their economic dispute via the official website of such an arbitration court.

The introduction of modern technologies into arbitration proceedings has allowed considering economic disputes using video conferencing tools. The system can organize two-member sessions and multipoint video conferences. In 2018, arbitration courts of the constituent entities of the Russian Federation examined 5,600 cases using video conferencing tools in conformity with the Arbitration Procedure Code of the Russian Federation (Federal Law No. 95-FZ, 2002 , art. 153.1). In addition, higher courts examined 18,100 cases through video conferencing (Federal Arbitration Courts, n.d.).

To ensure the proper and uniform application of legislative innovations by arbitration courts, the Plenum of the Supreme Arbitration Court of the Russian Federation issued Resolution No. 12 (2011) "on Applying the Arbitration Procedure Code of the Russian Federation in Conformity with Federal Law No. 228-FZ" (as amended on June 27, 2017). In addition, Decree No. 61 (2012) of the Plenum of the Supreme Arbitration Court of the Russian Federation, "on Ensuring the Principle of Free Speech in Arbitration Proceedings" (as amended on April 4,2014) clarifies the application of such innovations within the framework of the procedural legislation.

Federal Law No. 200-FZ (2011) dwelled on provisions of the Arbitration Procedure Code of the Russian Federation in relation to posting information about the time and place of court hearings on the official website of arbitration courts. Under this law, the publication of this information is considered as a proper notification of parties to a trial if the court has documents confirming that the persons involved were sent copies of the first judicial act in the case 
and the addressees received them (delivery confirmation, receipt or other postal documents), or there is some other proof of receiving information about arbitration proceedings by parties to a trial.

One more innovation relating to e-justice is connected with the adoption of Federal Law No. 86-FZ (2012). To consider some case under the simplified procedure, arbitration courts need to post statements of a case and the documents attached on their official websites under limited access. While accepting statements of a case, arbitration courts send parties to a trial the data necessary for their identification to ensure access to the materials of their "electronic case". The answer to the complaint received, evidence and other documents accepted by arbitration courts and attached to the case are also posted on their official websites and can be examined by parties to a trial via the Internet. Decree No. 10 (2017) of the Plenum of the Supreme Arbitration Court of the Russian Federation "on Some Aspects of Applying Provisions of the Civil Procedure Code of the Russian Federation and the Arbitration Procedure Code of the Russian Federation on Simplified Proceedings" clarifies the application of Federal Law No. 86-FZ (2012).

According to the amendments made to the Arbitration Procedure Code of the Russian Federation by Federal Law No. 166-FZ (2013), arbitration courts are obliged to disclose information on political appeals of state bodies, local self-government bodies, other agencies, organizations, officials or citizens received by judges of arbitration courts in the cases under their jurisdiction, presidents of arbitration courts, their deputies, presiding judges or the chairperson of a judicial panel on the cases under consideration by posting such data on the official website of a certain arbitration court.

To implement provisions of the Arbitration Procedure Code of the Russian Federation providing for the submission of electronic documents by filling the sample forms available on the official website of an arbitration court, the Supreme Arbitration Court of the Russian Federation has developed a "Temporary Procedure for Submitting E-Documents to the Russian Courts" (Order No. 1, 2011). Decree No. 252 (2016) of the Judicial Department of the Supreme Court 
of the Russian Federation approved a new "Procedure for Submitting E-Documents to the Russian Arbitration Courts, Including in the Form of Electronic Documents" (as amended on February 20, 2018). Decree No. 57 (2017) of the Plenum of the Supreme Court of the Russian Federation dwells on the application of procedural laws governing the use of electronic documents in the activities of courts of general jurisdiction and arbitration courts.

The further improvement of e-justice is associated with the adoption of the Order No. 362 (2015) of the Judicial Department of the Supreme Court of the Russian Federation "on Approving the List of Main Concepts and Terms Used in Legal Acts of the Judicial Department that Govern the Use of Information-Telecommunication Technologies in the Operation of Courts, Agencies of the Judicial Department in Constituent Entities of the Russian Federation and Institutions of the Judicial Department" (as amended on August $28,2019)$. The above-mentioned document was the first to offer the legal definition of e-justice as a "method and form of implementing the proceedings envisaged by law based on the use of information technologies in judicial activities, including the interaction of courts, individuals and legal entities in electronic (digital) form".

As we have mentioned earlier, the Russian courts of general jurisdiction gradually introduce certain elements of e-justice approved by arbitration courts into their legal proceedings and records management. Federal Law No. 451-FZ (2018) and Federal Law No. 197-FZ (2019) on amending the Civil Procedure Code of the Russian Federation, and the rules of civil procedural law in this area of legal relations were unified with the rules of arbitration proceedings.

While considering the future development of e-justice, we should note such a direction as providing parties to a trial with access to archives using information technologies. Currently, this measure is implemented in an outdated form. Most court cases are preserved on paper, therefore archivists have to spend considerable time searching for them. According to the Arbitration Procedure Code of the Russian Federation (Federal Law No. 95-FZ, 2002, art. 41), only parties to a trial have the right to familiarize themselves with 
the materials of their case, including those placed in the court's archive. The Concept of the Federal Target Program "Developing the Russian Judicial System for 2013-2020" adopted by Resolution No. 1735-r (2012) of the Government of the Russian Federation, plans to carry out a set of measures aimed at creating an electronic archive of court cases. At the same time, the implementation of these measures cannot be considered efficient.

Given the time-consuming and costly nature of this procedure, a qualitative breakthrough will be made by introducing new rules obliging the persons involved in some case to present procedural documents and written evidence with digital copies in the form of scanned documents attached into the Arbitration Procedure Code of the Russian Federation. It seems that the business entities involved in arbitration proceedings have technical and material capabilities to implement this measure. At the same time, the duty to scan all completed cases stored in the archives of arbitration courts should be assigned to specially created units of such courts.

However, it is unacceptable to assign this obligation to regular citizens in the framework of civil proceedings since it can be interpreted as an additional obstacle to justice.

The challenges faced by the Russian judicial system during the spread of coronavirus infection have led to the introduction of new digital technologies in the administration of justice in civil cases and economic disputes. In particular, about the consideration of cases by Russian arbitration courts using online meetings. The first such meeting was held at the Supreme Court of the Russian Federation on April 21, 2020; at the level of the first instance arbitration courts - on April 28, 2020.

During the normal functioning of state and public institutions, the legislator's attitude to this form of administration of justice was cautious. The use of online procedures seems to run counter to the principle of the immediacy of the hearing. This principle requires the adjudicating judge to personally examine the evidence presented by the parties in an adversarial process. Indeed, the presentation by the parties and the examination by the court of proof, in particular, 
material evidence or witness testimony, can cause technical and organizational difficulties during online meetings.

However, in the context of an increase in the incidence of coronavirus infection, using online meetings allowed preventing the total suspension of trials, as happened in the spring of 2020 .

Online meetings are held based on the information portal of arbitration courts (https://kad.arbitr.ru). The procedure for admission to e-justice is extremely simple and does not require significant technical or organizational costs. The only difficulty that a participant may face is the presence of an enhanced digital signature, which is necessary to send a petition to the arbitration court.

Despite the active use of online meetings in the arbitration process in the context of the pandemic, this form of administration of justice is not normatively enshrined in Russian legislation. Its use is experimental. However, its actual application without any legitimation contradicts of the Arbitration Procedure Code of the Russian Federation (Federal Law No. 95-FZ, 2002, art. 1; art. 3). According to the articles, the procedure for legal proceedings in arbitration courts is determined by the Constitution of the Russian Federation, Federal Constitutional Law "on the Judicial System of the Russian Federation", Federal Constitutional Law "on Arbitration Courts in the Russian Federation", Arbitration Procedure Code of the Russian Federation and other federal laws adopted in accordance with them. That is, the rules of legal procedure can be established only by the Federal Assembly of the Russian Federation, the representative and legislative body of state power in Russia. At present, the use of online processes is allowed only by departmental acts of the Supreme Court of the Russian Federation.

This problem can be resolved by introducing appropriate changes to the content of Articles 11, 64, 136, 155, 158, 159, 291.12 and 308.9 of the Arbitration Procedure Code of the Russian Federation (Federal Law No. 95-FZ, 2002). Along with a reference to the use of videoconferencing, it may also be indicated that it is permissible to use online meetings when considering economic disputes and other arbitration cases. We consider it reasonable to include Article 153.1 
"Participation in an online meeting" in the structure of the Arbitration Procedure Code of the Russian Federation (Federal Law No. 95-FZ) with the following content:

1. Persons participating in the case and other participants in the arbitration process may participate in a court session using online session systems subject to their request and if the arbitration court has the technical ability to conduct it.

2. The identification and verification of the powers of the participants are carried out based on copies of documents proving their identity and powers, submitted through the information portal of arbitration courts and certified by enhanced digital signatures.

3. When considering a case using online systems, a protocol is drawn up and a video recording of the hearing is conducted. The material carrier of the video recording is attached to the protocols of the court session (art. 153.1, inc. 1; inc. 2; inc. 3).

We believe that such changes should also be introduced into the civil procedural legislation. According to its rules, civil cases are considered, the participants of which are citizens who do not have the status of an individual entrepreneur.

The problem of adaptation to online processes has arisen not only in Russia. The scientific and practical literature on this issue notes that despite the significant progress made by courts around the world in moving to an online model of service delivery, even in advanced judicial systems, serious problems remain in terms of access to justice (Sourdin, Li \& McNamara, 2020; Sourdin \& Zeleznikow, 2020; Van Gelder, Kramer \& Themeli, 2020).

The other promising areas of justice informatization in Russia are as follows:

- To create cloud computing architecture and specialized cloud software for automating judicial and general records management, which enables the remote participation of parties to procedural actions from anywhere in the world having a device with the Internet access. At the same time, it is necessary to develop technical and legal mechanisms for identifying the party's personality and verifying their authority; 
- To form mobile courts using video conferencing tools to conduct on-site meetings in remote settlements. A technical base is supposed to be a passenger minibus with advanced functionality, etc.

The above-mentioned measures aim at improving access to justice in the Russian Federation, ensuring its openness and maximum transparency. Therefore, the measures taken to develop the current judicial system will increase the level of trust in the Russian justice and make the Russian economy more attractive for both national and foreign investors.

\section{Conclusions}

To sum up, we express our hope for the further digitalization of court proceedings and record-keeping procedures in the Russian courts. We believe that e-justice ensures the effective implementation of the principles of transparency, accessibility and legality of judicial protection in civil cases and economic disputes. Under force majeure circumstances, e-justice might be the only mechanism to grant citizens and organizations access to judicial protection.

The research goal to propose ways to resolve the existing problems concerned with the legal regulation of e-justice in the Russian Federation was achieved. We proposed the wording of amendments to the current Russian procedural legislation to legitimize online meetings held in arbitration courts during the pandemic.

We believe that the research results, after discussion and revision by the legislative bodies of state power in Russia, can be used as the basis for a draft law that fills the gaps in procedural legislation in the field of online processes.

\section{REFERENCES}

Borisova, V. F. (2019). Legal regulation directions of civil e-justice. Materials of the III International Scientific and Practical Conference, Tambov legal readings named after F.N. Plevako (pp. 209-213). Publishing House "Derzhavinsky", Tambov, R. F. Available: https://elibrary.ru/item.asp?id=42403529 
Bryantseva, O. V. \& Soldatkina, O. L. (2019). E-justice in Russia: issues and their possible solution. O.E. Kutafin University Bulletin, 12(64), 97-104. Available: https://cyberleninka. ru/article/n/elektronnoe-pravosudie-v-rossii-problemy-iputi-resheniya

Denisov, I. S. (2018). The development of e-justice in Russia. Bulletin of the st. Petersburg university of the mia of russia, 1(77), 101-104. Available: https://cyberleninka.ru/ journal/n/vestnik-sankt-peterburgskogo-universitetamvd-rossii?i=1082362

Dorzhiev, E. P. (2012). The electronic submission of documents to arbitration courts: provisional application. Arbitration and civil procedure, (7), 21-24.

Fedoseeva, N. N. (2011). Access to information on the operation of courts in the Russian Federation. Court Administrator, (1).

Fedoseeva, N. N. (2008). E-justice in Russia: concept, problems and perspectives. Arbitration and Civil Procedure, (9), 14-17. Available: https://www.twirpx.com/file/488604/

Fokov, A. P. (2011). The functioning of arbitration courts in the Russian Federation in 2010 and perspectives for developing e-justice. Rossiiskii sudya, (6).

Reshetnyak, V. I. (2011). The issue of e-justice in arbitration and civil proceedings. Lawyer, (9).

R.F. Chairman of the Government. (Sept. 20, 2012). On approval of the Concept of the federal target program "Development of the judicial system of Russia for 2013-2020". [Resolution No. 1735-r]. Available: http://www.consultant. ru/document/cons_doc_LAW_135603/

R.F. Federal Arbitration Courts. (n.d.) . The consideration of cases by arbitration courts in 2018. [Online]. Available: http:// arbitr.ru 
R.F. Supreme Arbitration Court. (Apr. 18, 2017). On some aspects of applying provisions of the Civil Procedure Code of the Russian Federation and the Arbitration Procedure Code of the Russian Federation on simplified proceedings. [Decree No. 10]. Russian newspaper, 88. Available: http://www.consultant.ru/document/cons_doc_LAW_215641/

R.F. Supreme Arbitration Court. (October 8, 2012). On ensuring the principle of free speech in arbitration proceedings. [Resolution No. 61]. Available: http://www.consultant.ru/document/cons_doc_LAW_137059/

R.F. Supreme Arbitration Court. (Feb. 17, 2011). On applying the Arbitration Procedure Code of the Russian Federation in conformity with Federal Law No. 228-FZ of July 27, 2010 "On amending the Arbitration Procedure Code of the Russian Federation. [Resolution No. 12]. Available: http://www. consultant.ru/document/cons_doc_LAW_111644/

R.F. Supreme Arbitration Court. (Jan. 12, 2011). Temporary procedure for submission of documents to the arbitration courts of the Russian Federation in electronic form. [Order No. 1]. Available: http://www.consultant.ru/document/cons_doc_ LAW_109727/

R.F. Supreme Arbitration Court. (Jul. 12, 2007). On posting information on the Internet sites of arbitration courts. [Letter No. VAS-S01/UIS-984]. Available: http://www.consultant. ru/document/cons_doc_LAW_70330/

R.F. Supreme Court. (Mar. 18, 2020). On halting the personal reception of citizens in courts. [Resolution 808]. Availabale: http:// www.consultant.ru/document/cons_doc_LAW_347974/

R.F. Supreme Court. (Dec. 26, 2017). On applying the legislation regulating the use of electronic documents by general jurisdiction and arbitration courts. [Decree No. 57]. Available: http://www.consultant.ru/document/cons_doc_ LAW_286321/ 
R.F. Supreme Court. (Dec. 28, 2016). On approval of the Procedure for filing documents in the arbitration courts of the Russian Federation in electronic form, including in the form of an electronic document. [Decree No. 252]. Available: http:// www.consultant.ru/document/cons_doc_LAW_209951/

R.F. Supreme Court. (Nov. 26, 2015). On approving the List of main concepts and terms used in legal acts of the Judicial Department that govern the use of information-telecommunication technologies in the operation of courts, agencies of the Judicial Department in constituent entities of the Russian Federation and institutions of the Judicial Department. [Order No. 362]. Available: https://docs.cntd.ru/document/420324231

R.F. State Duma. (Jul. 26, 2019). On Amendments to Certain Legislative Acts of the Russian Federation. [Federal Law No. 197-FZ]. Availalble: http://www.consultant.ru/document/ cons_doc_LAW_329959/

R.F. State Duma. (Nov. 28, 2018). On Amendments to Certain Legislative Acts of the Russian Federation. [Federal Law No. 451-FZ]. Availalble: http://www.consultant.ru/document/ cons_doc_LAW_312093/

R.F. State Duma. (Jun. 25, 2012). On amending the Arbitration Procedure Code of the Russian Federation to simplify court proceedings. [Federal Law No. 86-FZ]. Available: http:// www.consultant.ru/document/cons_doc_LAW_131581/

R.F. State Duma. (Jul. 2, 2013). On amending some legal acts of the Russian Federation. [Federal Law No. 166-FZ]. Available: http://www.consultant.ru/document/cons_doc_LAW_148477/

R.F. State Duma. (Jul. 11, 2011). On amending certain legislative acts of the Russian Federation due to the adoption of the Federal Law on information, information technologies and information security. [Federal Law No. 200-FZ]. Russian newspaper, 34. Available: http://www.consultant.ru/document/cons_doc_LAW_116562/ 
R.F. State Duma. (Jul. 27, 2010). On amending the Arbitration Procedure Code. [Federal Law No. 228]. Rossiiskaya gazeta, 169. Available: http://www.consultant.ru/document/cons_ doc_LAW_103105/

R.F. State Duma. (Dec. 22, 2008). On providing access to data on the operation of courts. [Federal Law No. 262-FZ]. Russian newspaper, 265. Available: http://www.consultant.ru/document/cons_doc_LAW_82839/

R.F. State Duma. (Jul. 27, 2006). On information, information technologies and information security. [Federal Law No. 149 FZ]. Russian newspaper, 165. Available: http://www.consultant.ru/document/cons_doc_LAW_61798/

R.F. State Duma. (jul. 24, 2002). The Arbitration Procedure Code of the Russian Federation. [Federal Law No. 95-FZ]. Russian newspaper, 137. Available: http://www.consultant.ru/document/cons_doc_LAW_37800/

R.F. State Duma. (apr. 28, 1995). On Arbitration Courts in the Russian Federation. [Federal Constitutional Law of No. 1-FKZ]. Available: http://www.consultant.ru/document/ cons_doc_LAW_6510/

Rogozhin, S. P. (2012). The specifics of ensuring e-justice. The Civilist, (2).

Rybkina, K. V. (2018). E-justice as a new structure in public administration. Gaps in Russian Legislation, (1), 120-126. Available: https://urvak.ru/articles/probe-vypusk-1-elektronnoepravosudie-kak-novaya-s/

Shilovskaya, A. L. \& Sitdikova, L. B. (2018). The Use of Restorative Justice for Juveniles in Europe. Russian journal of criminology, 12(1), 141-151. https://doi.org/10.17150/25004255.2018.12(1).141-151

Sitdikova, L. B. \& Starodumova, S. J. (2019). Corporate agreement as a means of providing security in the course of entrepreneurship development. Entrepreneurship and Sustainability Issues, 7(1), 324-335. https://doi.org/10.9770/jesi.2019.7.1(24) 
Sourdin, T. \& Zeleznikow, J. (2020). Courts, mediation and COVID-19. Australian Business Law Review, 48(2), 138-158.

Sourdin, T., Li, B. \& McNamara, D. M. (2020). Court innovations and access to justice in times of crisis. Health Policy and Technology, 9(4), 447-453. https://doi.org/10.1016/j. hlpt.2020.08.020

Spitsin, I. N. (2011). The mechanism ensuring the transparency of civil and arbitration proceedings: general characteristics. Russian Law Review, (2).

Usova, M. G. (2018). Relevant issues of e-justice. Civilistics: law and progress, 3(44), 132-136. Available: https://elibrary.ru/ item.asp?id=38236214

Van Gelder, E., Kramer, X. \& Themeli, E. (Apr. 7, 020). Access to justice in times of corona. When COVID-19 makes the case for greater digitalisation of justice. [Online]. Available: https://conflictoflaws.net/2020/access-to-justice-in-timesof-corona/

Vasnev, V. (2008). E-justice: results and perspectives. Bulletin of the Supreme Arbitration Court of the Russian Federation, (8), 58-59. Available: https://igzakon.ru/ list? year $=2013 \&$ type $=59$

Vdovina, E. (2009). Developing the principle of free speech in civil and arbitration proceedings. Arbitration and civil procedure, (10).

Vorontsova, I. V. (2019). The correlation between two concepts - "ecourt" and "e-justice. Legal policy and legal life, (3), 167169.

Yachmenev, G. G. (2012). Posting judicial acts on the Internet (legal aspects). Arbitration and civil proceedings, (7).

Yakovleva, A. P. (2019). Pros and cons of e-justice: seeking balance. Vestnik PVolga Region Management Institute Newsletter, 19(6), 73-79. https://doi.org/10.22394/1682-2358-2019-673-79 
Inna Leonidovna Burova, Ph.D. in Juridical Sciences, Russian State Social University (Russian Federation). http://orcid.org/00000002-3947-3142

Maria Alexandrovna Volkova, Ph.D. in Historical Sciences, Russian State Social University (Russian Federation). http://orcid. org/0000-0001-5928-6929

Renata Romanovna Lenkovskaya, Ph.D. in Juridical Sciences, Russian State Social University (Russian Federation). http://orcid. org/0000-0001-9309-3602 